\begin{abstract}
Iranica
Abstracta Iranica Revue bibliographique pour le domaine irano-aryen

Volume 37-38-39 | 2018

Comptes rendus des publications de 2014-2016
\end{abstract}

\title{
Nikolaus Schindel. « Sasanidische Bleimünzen »
}

\section{Rika Gyselen}

\section{(2) OpenEdition}

Journals

Édition électronique

URL : http://journals.openedition.org/abstractairanica/42637

DOI : 10.4000/abstractairanica.42637

ISBN : 1961-960X

ISSN : 1961-960X

Éditeur :

CNRS (UMR 7528 Mondes iraniens et indiens), Éditions de l'IFRI

Référence électronique

Rika Gyselen, « Nikolaus Schindel. « Sasanidische Bleimünzen » », Abstracta Iranica [En ligne], Volume 37-38-39 | 2018, document 11, mis en ligne le 10 mars 2018, consulté le 28 septembre 2020. URL : http://journals.openedition.org/abstractairanica/42637 ; DOI : https://doi.org/10.4000/ abstractairanica. 42637

Ce document a été généré automatiquement le 28 septembre 2020

Tous droits réservés 
Nikolaus Schindel. « Sasanidische Bleimünzen »

Rika Gyselen 


\section{RÉFÉRENCE}

Nikolaus Schindel. « Sasanidische Bleimünzen », W. Szaivert, N. Schindel, M. Beckers, K. Vondrovec (eds.), TOYTO APECH TH XWPA. Festschrift für Wolfgang Hahn zum 70. Geburtstag [Veröffentlichungen des Instituts für Numismatik und Geldgeschichte 16], Wien, 2015, p. 303-330. ISSN 978-3-9501987-5-10

1 Bien que le petit monnayage de circulation en plomb ait dû être très abondant à l'époque sassanide, on n'en connaît que quelque 150 alors qu'on compte les monnaies d'argent par milliers, et les monnaies de cuivre par centaines (voir p. 305, Tab. 1).

2 En guise d'introduction, l'auteur passe en revue, d'une manière critique, de nombreux avis de numismates concernant le monnayage de plomb sassanide.

3 L'auteur a procédé à un réexamen très minutieux de toutes les monnaies de plomb publiées ce qui, entre autres, l'a mené à corriger plusieurs attributions chronologiques. Il est parvenu à la conclusion qu'aucune production de monnaies de plomb n'existe avant Wahrām II ni après Pērōz. Aussi pour d'autres règnes, il y a parfois absence de monnaies de plomb ce qui est expliqué par le hasard dont souffre la documentation. Cette analyse détaillée a permis de découvrir quelques nouveaux types monétaires et d'identifier le style de plusieurs autres. Ont été examinés ensuite : les lieux de frappes, les lieux de découverte et la métrologie.

4 Cette contribution se termine par un catalogue de 148 monnaies de plomb et quelques reproductions de monnaies qui soulignent la difficulté de lecture de ce petit monnayage souvent mal conservé auquel est consacré ici la première étude exclusive. On peut évidemment regretter que ce monnayage de plomb n'a fait l'objet d'aucune analyse élémentaire.

\section{AUTEURS}

\section{RIKA GYSELEN}

CNRS, Mondes iranien et indien 